\title{
Growing attention to an old marker, hepatitis B surface antigen, in the natural history of chronic hepatitis $B$
}

\author{
Jeong Won Jang \\ Department of Internal Medicine, College of Medicine, WHO Collaborating Center on Viral Hepatitis, \\ The Catholic University of Korea, Seoul, Korea
}

\section{Serum hepatitis B surface antigen and hepatitis $B$ e antigen titers: disease phase influences correlation with viral load and intrahepatic hepatitis B vinus markers.}

\section{Thompson AJ, Nguyen T, Iser D, Ayres A, Jackson K, Littlejohn M, Slavin J, Bowden S, Gane EJ, Abbott W, Lau GK, Lewin SR, Visvanathan K, Desmond PV, Locarnini SA.}

Hepatology 2010;51:1933-1944.

Hepatitis B surface antigen ( $\mathrm{HBs} A g)$, originally referred as to "Australia antigen" was discovered approximately 40 years ago. Over the years, the presence of this antigen has remained the hallmark of hepatitis B virus (HBV) infection. $\mathrm{HBs} A g$ is the viral envelope and is composed by 3 proteins, such as $\mathrm{S}$ (small, $\mathrm{S}$ domains), M (medium, preS2+S) and L (large, preS1+preS2+S) codified by only one open reading frame. The S-HBs protein is the major component of the virion envelope and the subviral HBsAg particles, such as filaments and spheres, while virions and filaments contain more M-HBs, and in particular, more L-HBs proteins than spheres. ${ }^{1,2}$ In infected individuals, subviral particles are present in at least 100 -fold excess over virions. ${ }^{3}$ The processing of production and secretion of HBsAg is complex, and the comparative proportion of each S-, M-, L-HBsAg component in the serum and liver varies according to the state of HBV replication. ${ }^{4}$

The recent growing interest in quantitative analysis of $\mathrm{HBsAg}$ as a clinical parameter has been based on several studies that observed its relationship with serum and liver HBV DNA. ${ }^{5-7}$ In fact, quantification of HBsAg was introduced more than 20 years ago, but its clinical usefulness has been questioned due to the lack of appropriate standardization. ${ }^{8}$ Consequently, HBsAg has long been used typically as a qualitative marker for diagnosing an ongoing HBV infection. Recently, a quantitative, fully automated chemiluminescent microparticle immunoassay for the detection of HBsAg became available and offered more reliable quantitative data for HBsAg at a wide range of concentrations. ${ }^{5}$ It has been suggested that serum HBsAg levels correlate well with intrahepatic amounts of total HBV DNA and covalently closed circular DNA (cccDNA), which is responsible for viral persistence. ${ }^{6,7}$ Furthermore, reduction in HBsAg serum levels reportedly provided good predictive ability in patients treated with antiviral therapy. In HBeAg-negative individuals, serum HBsAg levels $<10 \mathrm{IU} / \mathrm{mL}$ at week 48 and on-treatment decline $>1 \log \mathrm{IU} / \mathrm{mL}$ have been significantly associated with sustained HBsAg clearance 3 years after treatment, while a decrease of 0.5 $\log \mathrm{IU} / \mathrm{mL}$ and $1 \log \mathrm{IU} / \mathrm{mL}$ in HBsAg levels at weeks 12 and 24 of therapy, respectively, have high predictive values of a sustained virologic response. ${ }^{9,10}$ Although these results suggest the potential clinical usefulness of quantitative HBsAg as an on-treatment predictor, such a good correlation was only observed in the setting of immunomodulatory agents (pegylated interferon therapy). ${ }^{9,10}$ Thus, whether or not HBsAg serum levels are still efficient as a marker for on-treatment prediction for

Keywords: Hepatitis B virus; Hepatitis B surface antigen; Chronic hepatitis B; Korea

Abbreviations: HBsAg, Hepatitis B surface antigen; HBV, hepatitis B virus; cccDNA, covalently closed circular DNA

Corresponding author: Jeong Won Jang

Department of Internal Medicine, Incheon St. Mary’s Hospital, 665 Bupyeong 6-dong, Bupyeong-gu, Incheon 403-720, Korea

Tel. +82-32-510-5682, Fax. +82-32-510-5683, E-mail; garden@catholic.ac.kr 
response to oral nucleos(t)ide analogues remains to be determined in future studies.

The significance of HBsAg levels in the natural course of $\mathrm{HBV}$ infection is another key issue in need of detailed evaluation. In fact, $\mathrm{HBV}$ replication and $\mathrm{HBs} \mathrm{Ag} / \mathrm{HBV}-\mathrm{DNA}$ production go through a complex process, which accompanies highly dynamic changes during the long-lasting interaction between virus and host immunity. More recently, the role of quantification of serum HBsAg has been explored in a subset of European and Asian HBV-infected cohorts. The overall correlation between HBsAg and HBV DNA levels was noted in both study populations. ${ }^{8,11}$ However, when it was analyzed separately by different phases of chronic HBV infection or by HBV genotypes, the correlation was shown to become weak or negligible. ${ }^{8,11}$ More specificially, a positive correlation between serum $\mathrm{HBsAg}$ and $\mathrm{HBV}$ DNA levels was only observed in the early phases of infection, but disappeared in the late phases (HBeAg-negative status). Indeed, the correlation was totally absent for patients with HBV genotype $\mathrm{A}^{8}$

The direct link between HBsAg and HBV DNA levels is an intriguing issue. Theoretically, the levels of the virion and $\mathrm{HBsAg}$ production would be correlated, if a potent host immune targets concordantly both virion and HBsAg synthesis processes, leading to the effective control of HBV replication. However, the immune target of host against viral replication versus $\mathrm{HBsAg}$ pathways may not remain in continued concordance through the natural course of infection. As noted in relevant studies, ${ }^{8,11}$ the $\mathrm{HBsAg} / \mathrm{HBV}$ DNA ratios are significantly higher in the low replicative phase than other phases of infection, irrespective of study population. This may suggest that subviral particles are

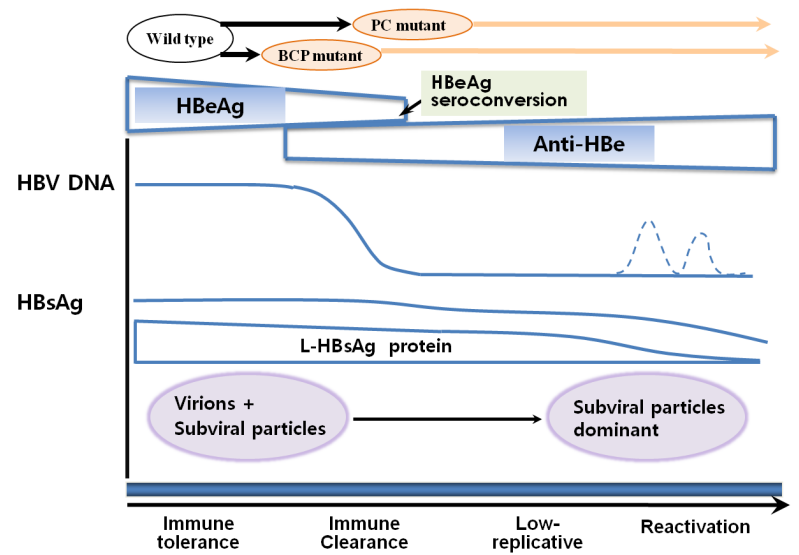

Figure 1. Schematic changes in $\mathrm{HBs} \mathrm{Ag}, \mathrm{HBeAg}, \mathrm{BCP} / \mathrm{PC}$ mutants, and HBV DNA levels during the natural course of chronic hepatitis $\mathrm{B}$ in the Korean population with genotype $\mathrm{C}$. $\mathrm{BCP}$, basal core promoter; $\mathrm{PC}$, precore. produced far in excess of virions, with altered production of HBsAg between its three components of $\mathrm{L}, \mathrm{M}$, and $\mathrm{S}$ proteins, in this subset of patients. ${ }^{4}$ Thus, the relationships between HBsAg and HBV DNA levels should be understood in light of the predominant pathway of HBsAg production versus viral replication in the course of chronic HBV infection (Fig. 1).

It is well known that nearly all ( $>95 \%)$ chronic HBV carriers in Korea have genotype $\mathrm{C},{ }^{12-16}$ which is associated with a high prevalence of basal core promoter mutants, even before $\mathrm{HBeAg}$ seroconversion. ${ }^{14-16}$ In this context, it needs to be determined how serum $\mathrm{HBs} A g$ concentration functions in the natural history of $\mathrm{HBV}$ infection within the same category of genotype $\mathrm{C}$ associated with particular viral variants among the Korean population. Recent Korean studies involving a large number of antiviral-naïve patients at various disease stages of hepatitis B have shown varying clinical significance of HBsAg levels according to the disease phases. ${ }^{17-19}$ Cross-sectional studies in Korea by Yoo et al. ${ }^{17}$ and Kim et al. ${ }^{18}$ yielded similar findings regarding $\mathrm{HBsAg}$ levels related to the natural course of $\mathrm{HBV}$ infection (Table 1). In agreement with the previous European and Asian cohort studies, ${ }^{8,11} \mathrm{HBs} A g$ levels in the two Korean studies were highest at 4.1-4.2 $\log \mathrm{IU} / \mathrm{mL}$ in the immune tolerant phase and lowest at 2.3-3.1 $\log \mathrm{IU} / \mathrm{mL}$ in the low replicative phase during the course of HBV infection. ${ }^{17,18}$ The overall relationship between serum HBsAg and HBV DNA levels was modest $(r=0.383-0.700)$. With a stratified analysis by HBeAg status, there was a tendency for a better correlation between HBsAg and HBV DNA in HBeAg-positive patients ( $\mathrm{r}=0.463-0.706)$, as compared to HBeAg-negative patients $(\mathrm{r}=0.064-0.521)$. In both studies, age was consistently identified to be negatively correlated with serum HBsAg levels, indicating that production of $\mathrm{HBsAg}$ proteins gradually decreases with age, under effective immune control of HBV replication and HBsAg synthesis. ${ }^{17,18}$ One of the important concerns in studies involving the natural history of $\mathrm{HBV}$ is the fact that the classification of disease stage in HBV carriers is not always certain, and rather, many individuals are indeed on the border between different stages of HBV infection. Given that liver biopsies are not routinely performed in all patients, the current categorizing system depending on a single time point measurement of $\mathrm{HBeAg}$ and HBV DNA can potentially result in the misdiagnosis of a disease stage, because of the highly fluctuating nature of serum HBV DNA levels in each patient. For this reason, it is highly likely that multiple serial measurements of virologic markers rather than reliance on only a single measurement may improve the acceptance of its value to 


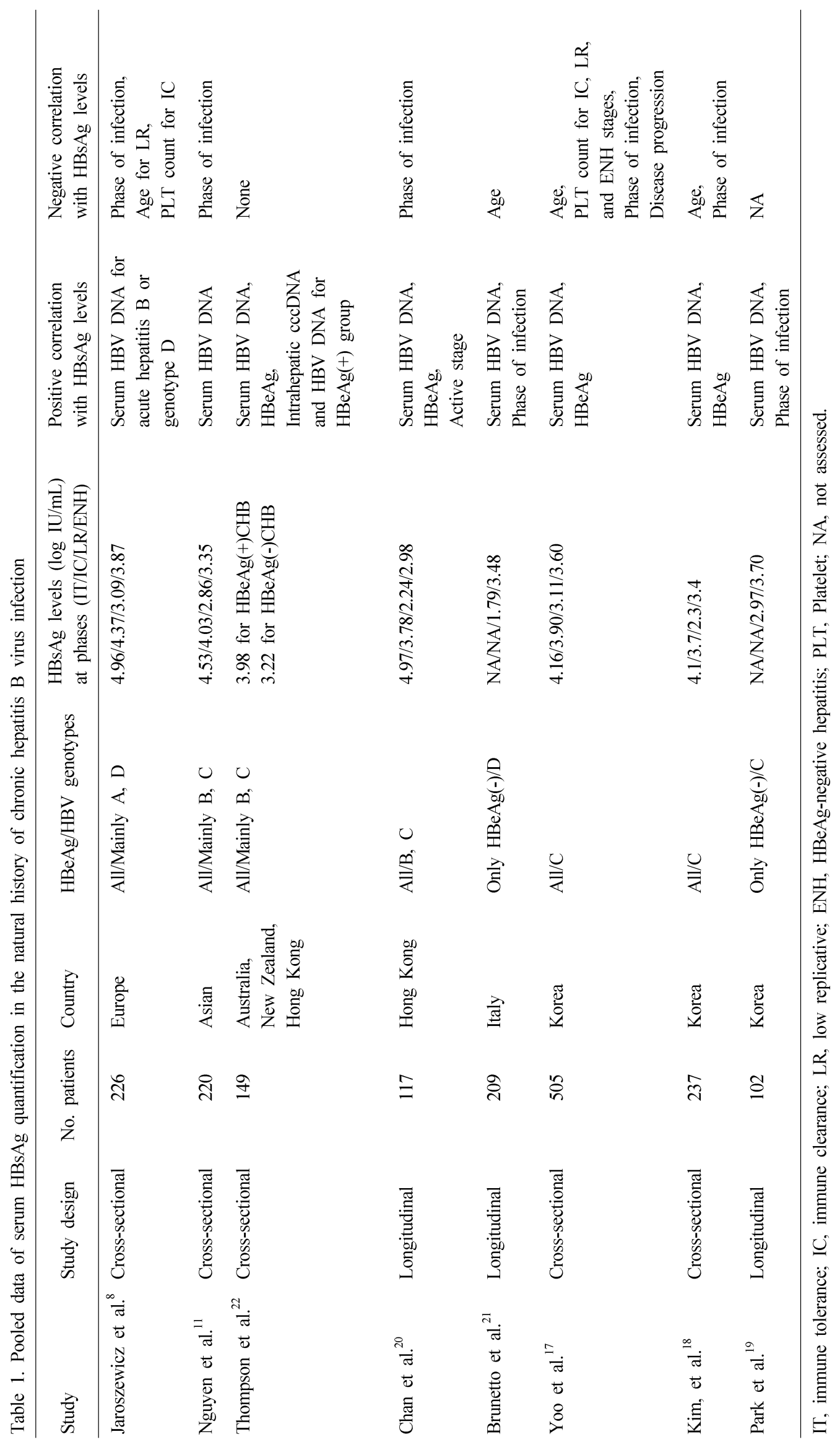


discriminate a specific stage during the natural course of hepatitis B. With the introduction of HBsAg quantification in current practice, whether or not the employment of HBsAg quantification may also have a beneficial role in diagnosing the different stages of chronic hepatitis B is another issue to be further confirmed.

With respect to this issue, the study by Chan et al., ${ }^{20}$ involving 117 Chinese patients with chronic hepatitis $\mathrm{B}$, investigated the changes in HBsAg level during the natural progression of disease. With a longitudinal follow-up of the untreated cohort for $99 \pm 16$ months, they showed that HBsAg levels in patients at immune tolerant phase remain stable and persistently high at approximately $5 \log \mathrm{IU} / \mathrm{mL}$. Then, the levels at immune active stage or around the time of $\mathrm{HBeAg}$ seroconversion were comparatively lower at 3-4 log IU/mL. After achieving $\mathrm{HBeAg}$ seroconversion, the HBsAg level decreased progressively with time. An $\mathrm{HBsAg}$ reduction of $>1 \log \mathrm{IU} / \mathrm{mL}$ in $\mathrm{HBeAg}$-negative patients resulted in a better viral control, with an increased chance of HBsAg loss during extended follow-up. In this study, however, no clear cut-off value of HBsAg serum level discriminated $\mathrm{HBeAg-negative} \mathrm{patients} \mathrm{between} \mathrm{immuno-active}$ and -inactive diseases due to significant overlap of HBsAg levels and a highly fluctuating levels of serum HBV DNA among these patients. In contrast to the results, another study involving 209 European patients with $\mathrm{HBeAg-negative} \mathrm{hepatitis} \mathrm{and} \mathrm{genotype}$ D indicated that quantification of both HBsAg and HBV DNA levels better discriminated between the two phases in HBeAgnegative patients, that is, a single-point combined quantification for HBsAg $(<1,000 \mathrm{IU} / \mathrm{mL})$ and HBV DNA $(<2,000 \mathrm{IU} / \mathrm{mL})$ yielded the most accurate identification of inactive carriers with a $94.3 \%$ diagnostic accuracy, comparable with that of long-term tight monitoring. ${ }^{21}$ A recent Korean study by Park et al., ${ }^{19}$ in which $102 \mathrm{HBeAg-negative} \mathrm{patients} \mathrm{were} \mathrm{recruited,} \mathrm{also}$ attempted to determine the value of $\mathrm{HBsAg}$ quantification for determining outcome of $\mathrm{HBeAg-negative} \mathrm{hepatitis.} \mathrm{In} \mathrm{this} \mathrm{study,}$ the cut-off value for HBsAg that provided the best predictive accuracy to discriminate inactive carriers from active carriers was $3.25 \log \mathrm{IU} / \mathrm{mL}$ for the non-cirrhosis group and $2.57 \log$ $\mathrm{IU} / \mathrm{mL}$ for the cirrhosis group (Table 1).

One key question for understanding the role of $\mathrm{HBsAg}$ quantification in the natural course of $\mathrm{HBV}$ infection is its relationship with circulating $\mathrm{HBe} \mathrm{Ag} / \mathrm{HBV}$ DNAlevels, intrahepatic $\mathrm{HBV}$ replicative intermediates, and the significance of emerging viral variants. The study by Thompson et al. ${ }^{22}$ addressed these critical issues through a comprehensive analysis of serum and liver markers of $\mathrm{HBV}$ replication in 149 treatment-naïve patients. There were significant differences in HBsAg expression between patients with $\mathrm{HBeAg}$-positive and $\mathrm{HBeAg}$-negative chronic hepatitis B. In HBeAg-positive patients, HBsAg was positively correlated with serum HBV DNA and intrahepatic cccDNA and total HBV DNA ( $\mathrm{r}=0.69-0.76)$. Additionally, HBeAg levels also correlated with serum HBV DNA levels $(\mathrm{r}=0.60)$, although the emergence of basal core promoter/precore variants decreased $\mathrm{HBeAg}$ levels independent of viral replication. By contrast, in $\mathrm{HBeAg-negative} \mathrm{patients,} \mathrm{HBsAg}$ correlated poorly with serum HBV DNA ( $r=0.28)$, with no correlation between $\mathrm{HBsAg}$ and intrahepatic $\mathrm{HBV}$ replicative intermediates. Similarly, HBsAg expression, as measured by quantitative immunohistochemical staining, also showed a positive correlation with viral replication only in $\mathrm{HBeAg}$ positive patients, but not in $\mathrm{HBeAg-negative} \mathrm{patients.} \mathrm{The}$ disconnect between $\mathrm{HBsAg}$ production and $\mathrm{HBV}$ replication in the $\mathrm{HBeAg}$-negative phase of disease implies that HBsAg might be produced from additional pathways other than $\mathrm{HBV}$ replication pathway from intranuclear cccDNA. HBV replication in the life cycle of $\mathrm{HBV}$ requires encapsidation of the pre-genomic RNA by the core particle. Under strong immune pressure associated with the HBeAg-negative phase, intracellular inhibitory cytokines more preferentially inhibit the encapsidation process, sparing the HBsAg synthesis pathway. On the other hand, HBsAg can also be produced from viral segments integrated into the host genome, which often carry the sequences of the $\mathrm{S}$ genes, although the integrated sequences are not able to allow for viral replication. ${ }^{22}$ In this context, $\mathrm{HBsAg}$ production in $\mathrm{HBeAg}$-negative carriers is preserved relative to $\mathrm{HBV}$ replication for a quite long time, even after $\mathrm{HBeAg}$ seroconversion. Taken together, these findings indicate that the relationships between $\mathrm{HBs} A g, \mathrm{HBeAg}$, serum HBV DNA, and HBV replicative intermediates are not simple, but depend on the complex interplay between host and viral factors evolving over a long-lasting inflammatory process.

In conclusion, quantitative HBsAg assays, which are easy to perform with low cost, would help to assess the stage of chronic hepatitis $\mathrm{B}$, intrahepatic viral replicative status, and response to antiviral therapy. Despite such potential usefulness, there is extremely limited evidence to support the definitive role of HBsAg quantification as a clinical biomarker for the management of chronic hepatitis B. Studies show that the production of HBsAg likely undergoes evolutionary changes by a complex interplay between virus and host, during the natural history of chronic HBV infection. Thus, it is mandatory to further test the 
value of quantification of this antigen in clinical practice based on additional studies.

\section{REFERENCES}

1. Stibbe W, Gerlich WH. Structural relationships between minor and major proteins of hepatitis B surface antigen. J Virol 1983;46:626-628.

2. Heermann KH, Goldmann U, Schwartz W, Seyffarth T, Baumgarten H, Gerlich WH. Large surface proteins of hepatitis B virus containing the pre-s sequence. J Virol 1984;52:396-402.

3. Seeger C, Mason WS. Hepatitis B virus biology. Microbiol Mol Biol Rev 2000;64:51-68.

4. Dienes HP, Gerlich WH, Worsdorfer M, Gerken G, Bianchi L, Hess G, et al. Hepatic expression patterns of the large and middle hepatitis B virus surface proteins in viremic and nonviremic chronic hepatitis B. Gastroenterology 1990;98:1017-1023.

5. Deguchi M, Yamashita N, Kagita M, Asari S, Iwatani Y, Tsuchida T, et al. Quantitation of hepatitis B surface antigen by an automated chemiluminescent microparticle immunoassay. J Virol Methods 2004;115:217-222.

6. Werle-Lapostolle B, Bowden S, Locarnini S, Wursthorn K, Petersen J, Lau G, et al. Persistence of cccDNA during the natural history of chronic hepatitis $\mathrm{B}$ and decline during adefovir dipivoxil therapy. Gastroenterology 2004;126:1750-1758.

7. Wursthorn K, Lutgehetmann M, Dandri M, Volz T, Buggisch P, Zollner $\mathrm{B}$, et al. Peginterferon alpha-2b plus adefovir induce strong cccDNA decline and HBsAg reduction in patients with chronic hepatitis B. Hepatology 2006;44:675-684.

8. Jaroszewicz J, Calle Serrano B, Wursthorn K, Deterding K, Schlue J, Raupach R, et al. Hepatitis B surface antigen (HBsAg) levels in the natural history of hepatitis B virus (HBV)-infection: a European perspective. J Hepatol 2010;52:514-522.

9. Brunetto MR, Moriconi F, Bonino F, Lau GK, Farci P, Yurdaydin C, et al. Hepatitis B virus surface antigen levels: a guide to sustained response to peginterferon alfa-2a in $\mathrm{HBeAg-negative} \mathrm{chronic} \mathrm{hepatitis}$ B. Hepatology 2009;49:1141-1150.

10. Moucari R, Mackiewicz V, Lada O, Ripault MP, Castelnau C, Martinot-Peignoux M, et al. Early serum HBsAg drop: a strong predictor of sustained virological response to pegylated interferon alfa-2a in HBeAg-negative patients. Hepatology 2009;49:1151-1157.

11. Nguyen T, Thompson AJ, Bowden S, Croagh C, Bell S, Desmond PV, et al. Hepatitis B surface antigen levels during the natural history of chronic hepatitis B: a perspective on Asia. J Hepatol 2010;52:508-513.

12. Lee JM, Ahn SH, Chang HY, Shin JE, Kim DY, Sim MK, et al. Reappraisal of HBV genotypes and clinical significance in Koreans using MALDI-TOF mass spectrometry. Korean J Hepatol 2004; 10:260-270.

13. Bae SH, Yoon SK, Jang JW, Kim CW, Nam SW, Choi JY, et al. Hepatitis $\mathrm{B}$ virus genotype $\mathrm{C}$ prevails among chronic carriers of the virus in Korea. J Korean Med Sci 2005;20:816-820.

14. Song BC, Cui XJ, Kim HU, Cho YK. Sequential accumulation of the basal core promoter and the precore mutations in the progression of hepatitis B virus-related chronic liver disease. Intervirology 2006; 49:266-273.

15. Jang JW, Lee YC, Kim MS, Lee SY, Bae SH, Choi JY, et al. A 13-year longitudinal study of the impact of double mutations in the core promoter region of hepatitis $\mathrm{B}$ virus on $\mathrm{HBeAg}$ seroconversion and disease progression in patients with genotype $\mathrm{C}$ chronic active hepatitis. J Viral Hepat 2007;14:169-175.

16. Yoo BC, Park JW, Kim HJ, Lee DH, Cha YJ, Park SM. Precore and core promoter mutations of hepatitis $\mathrm{B}$ virus and hepatitis $\mathrm{B}$ e antigen-negative chronic hepatitis B in Korea. J Hepatol 2003;38:98-103.

17. Yoo SH, Jang JW, Kwon JH, Chang UI, Nam SW, Choi JY, et al. Significance of hepatitis B surface antigen levels in the natural history and disease stage of hepatitis B virus-related liver diseases in Korea [Abstract]. Korean J Hepatol 2010;16(S3):S32.

18. Kim YJ, Cho HJ, Choi MS, Lee JH, Koh KC, Yoo BC, et al. Association between quantitative $\mathrm{HBsAg}$ and serum HBV DNA levels in chronic hepatitis B patients [Abstract]. Korean J Hepatol 2010;16(S3):S31.

19. Park H, Lee JM, Kim HS, Ahn SH, Kim DY, Han KH, et al. Predictive value of HBsAg quantification for determining clinical course in HBeAg negative carriers [Abstract]. Korean J Hepatol 2010;16(S3):S33.

20. Chan HL, Wong VW, Wong GL, Tse CH, Chan HY, Sung JJ. A longitudinal study on the natural history of serum hepatitis B surface antigen changes in chronic hepatitis B. Hepatology 2010 Jun 11. [Epub ahead of print].

21. Brunetto MR, Oliveri F, Colombatto P, Moriconi F, Ciccorossi P, Coco $B$, et al. Hepatitis B surface antigen serum levels help to distinguish active from inactive hepatitis B virus genotype D carriers. Gastroenterology 2010;139:483-490.

22. Thompson AJ, Nguyen T, Iser D, Ayres A, Jackson K, Littlejohn M, et al. Serum hepatitis B surface antigen and hepatitis B e antigen titers: disease phase influences correlation with viral load and intrahepatic hepatitis B virus markers. Hepatology 2010;51:1933-1944. 